\title{
CALCULATIONS OF SUPRAMOLECULAR STRUCTURES OF PEPTIDYLBORONIC ACID (BORTEZOMIB) WITH ABO BLOOD SYSTEM ANTIGEN
}

\author{
A. D. KUSTOVSKA ${ }^{1 凶}$, S. V. PRYMACHENKOㄹ, Zh. M. MINCHENKO', \\ T. F. LIUBARETS ${ }^{2}$, O. O. DMYTRENKO \\ ${ }^{1}$ National Aviation University, Kyiv, Ukraine; \\ e-mail: akust@bigmir.net; \\ ${ }^{2}$ SI "National Research Center for Radiation Medicine of National \\ Academy of Medical Sciences of Ukraine", Kyiv, Ukraine
}

Received: 08 April 2019; Accepted: 17 May 2019

\begin{abstract}
Peptidylboronic acids have recently become widespread as effective drugs for cancer treatment. However, the use of these drugs is often accompanied by negative side effects associated with the phenotypic affiliation to the ABO system. Therefore, it is important to determine the role of pharmaco-chemical characteristics of antigens of $A B O$ system and therapeutic agents (for example, bortezomib) in the selection of individualized therapies for patients with chronic lymphoproliferative neoplasms. The expediency and efficiency of bortezomib use for patients with plasma cell myeloma depending on the phenotype affiliation to the ABO system were evaluated. Efficiency of plasma cell myeloma therapy was analyzed in 104 patients who received treatment according to clinical protocols. Dependence of the duration of remission in performance of standard polychemotherapy was researched. Calculation of energy parameters and geometry of probable supramolecular structures of peptidylboronic (bortezomib) and boric acids with antigens of the ABO blood system was performed in the HyperChem 8.07 software package. It was demonstrated that the ability of antigens to form supramolecular complexes with bortezomib varies in the series: B1 >> $01>A 1$, which is in line with the results of clinical researches. It was assumed that in case of patients with B blood group secondary process (interaction of bortezomib with carbohydrate antigen) is energetically more beneficial than the main process (inhibition of proteasome), while for patients with $O$ and A groups, equilibrium is shifted toward the main reaction, which results in the therapeutic effect of the drug.
\end{abstract}

Ke ywords: peptidylboronic acids, supramolecular structures, ABO antigens, bortezomib, boric acids.

$\mathrm{B}$ oronic acids and esters of boronic acids are well-known for various pharmaceutically useful biological properties [1], in particular they are advanced inhibitors of function of proteasomes and multicatalytic protease, which is responsible for the cycling of most intracellular proteins. Protease inhibition is a new and important strategy for treating cancer. The first inhibitor of proteasomes, which has received legislative approval, is bortezomib (N-2-pyrazinecarbonyl-L-phenylalanine-Lleucineboronic acid). This pharmaceutical is intended to suppress specific molecular pathways critical to the survival of tumor cells. Today it is used to treat plasma cell myeloma and passes clinical tests for other types of cancer. Bortezomib is an inhibitor of the 20S proteasome and promotes the apoptosis of cancer cells that have lost the alternative proteasome [2-6].

Structurally, bortezomib belongs to the class of peptidylboronic acids, which are organic trivalent boron compounds ( $\mathrm{sp}^{2}$ hybridization) containing one peptide substituent (one B-C bond) and two hydroxyl groups (Fig. 1).

In the molecules of boronic acids, the principle of biomimicry $[7,8]$ is realized, when boron, which easily changes the state of hybridization from

\footnotetext{
(C) 2019 Kustovska A. D. et al. This is an open-access article distributed under the terms of the Creative Commons Attribution License, which permits unrestricted use, distribution, and reproduction in any medium, provided the original author and source are credited.
} 
<smiles>CC(C)CCNC(=O)[C@H](Cc1ccccc1)NC(=O)c1cnccn1</smiles>

Fig. 1. Structural formula of bortezomib

$\mathrm{sp}^{2}$ to $\mathrm{sp}^{3}$, is an analogue of carbon in the sense of the formation of bonds, but not in the sense of reactions that are the essence of biochemical processes, namely the reactions of effective enzyme inhibitors. Peptidylboronic acids are used as peptide analogs with specific functions. It is considered that the inhibiting of proteasome by such acids occurs by the formation of covalent adducts of tetracoordinate borate with active enzyme centers. The active center, in the form of hydroxyl group of $\mathrm{N}$-ended residue of threonine of catalytically active proteasome, covalently binds to the boron atom of bortezomib in the enzyme-inhibitor complex [1], with the boron passing into the tetrahedral form, thereby simulating the corresponding tetrahedral intermediate product of amidolysis (Fig. 2).

In addition, hydroxyl groups of boronic acids may form hydrogen bonds with other functional groups, such as histidine (Fig. 3), which complementarily stabilize the complex [1]. As a result, bortezomib can form a stable complex with proteasome and therewith show the inhibitory effect.

In addition to the ability of boronic acids to create stable proteasomes complexes, their important property is the propensity to form supramolecular systems with polyhydroxy compounds $[1,9,10]$.

These processes are more favorable in alkaline solutions, where in the high concentration, there is four-coordinated borate ion (equation 1, Fig. 4). Ex-

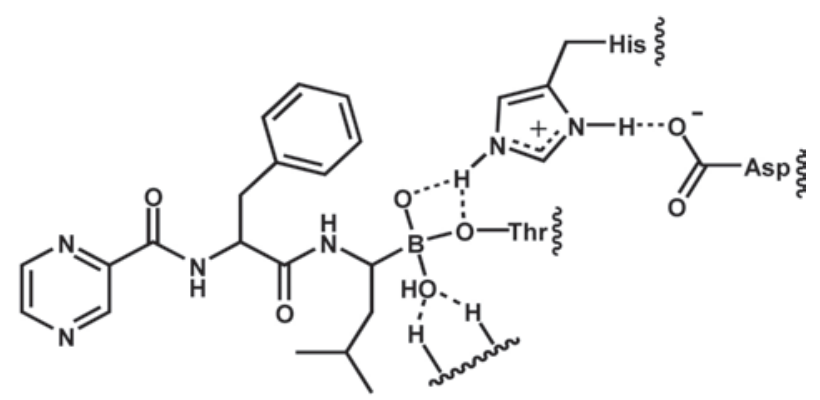

Fig.3. Stabilization of enzyme-bortezomib complex<smiles>CCCCCCCCCCC(=O)C(N)C(C)O[B-](O)(O)C(CC(C)C)NC(=O)C(Cc1ccccc1)NC(=O)c1cnccn1</smiles>

Fig. 2. Structure of enzyme-bortezomib complex

planation of the favorable thermodynamics of fourcoordinated boron ethers formation may lay in the formation of hydroxyboronate complexes with more advantageous configuration, as a result of boron rehybridization from $\mathrm{sp}^{2}$ to $\mathrm{sp}^{3}$ (valence angles from $120^{\circ}$ to $109^{\circ}$ ). The formation of such kind of supramolecular systems with bortezomib can be the cause of side effects from the action of the drug.

Despite the fact that bortezomib is clinically approved pharmaceutical, studies in animals revealed its hematologic, cardiac, gastrointestinal and neurological, renal toxicity [11-13]. The main idea of the work is based on the study of possibility of antigen-specific interaction of $\mathrm{ABO}$ determinants with the drug in patients with plasma cell myeloma (PCM), complicated by the presence of chronic renal failure (CRF), depending on the response to treatment in order of interpretation of results of clinical researches. The paper analyzes the likelihood of complications of therapy due to the possible formation of supramolecular structures of bortezomib with carbohydrates of antigens $\mathrm{ABO}$ of the blood system.

\section{Materials and Methods}

The effectiveness of PCM therapy was analyzed in 104 patients who received treatment according to clinical protocols recommended by the resolution (number 13 03/07/2015) of the Medical Ethics Committee in the Department of Radiation Oncohematology and Stem Cells Transplantation at the

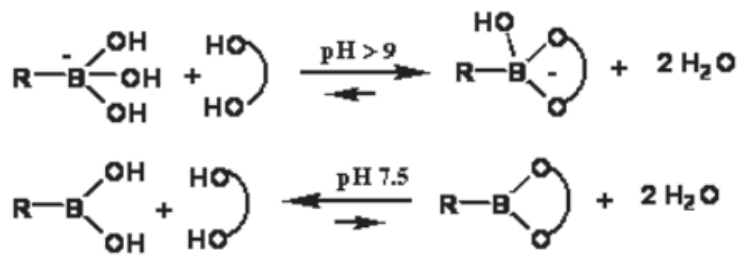

Fig. 4. Scheme of complexes creation of $B A$ and polyhydroxy compounds 
Institute of Clinical Radiology at the State Institution "National Research Center for Radiation Medicine of National Academy of Medical Sciences of Ukraine”. Dependence of remission duration during the standard polychemotherapy (PCT) was studied. The criteria for a positive response to treatment program were determined on the basis of the absence of infectious complications and decrease of the level of clinical and hematological parameters that determine the degree of CKD - urea and creatinine.

The hypothesis of the formation of bortezomib complexes with carbohydrates of antigens of blood groups is supported by the fact that the dependence of the effectiveness of its application on the carriage of phenotype of $\mathrm{ABO}$ was noted precisely for patients with CRF characterized by labile $\mathrm{pH}$ of blood serum. If necessary, some patients received drugs that reduce acidity, thereby creating a local increase in $\mathrm{pH}$ of the biological medium, which, in turn, may contribute to the flow of reaction 1 (Fig. 4).

In the antigens of the blood groups A and B, the final monosaccharide is galactose $\mathrm{N}$-acetyl substituted in position 2 (antigen A) and unsubstituted (antigen B). Galactose is also prefinal monosaccharide antigen $\mathrm{O}$. It is known that boronic acids with high selectivity create complexes with sugars, and with galactose in particular [14-16]. The absence of substituents in the final galactose of antigen B likely makes it more available for complex formation than the galactose of antigens $\mathrm{A}$ and $\mathrm{O}$. To verify this assumption, it was considered appropriate to investigate the possibility of formation of complex of bortezomib with galactose antigens at positions 3,4 where $\mathrm{OH}$-groups are in the cis-position. For this purpose, the calculation of possible complexes with four-coordinated boron was performed (Fig. 5). To simplify the model, the influence of the peptide part of antigens was not taken into account.

The compounds of boric acid are usually stable enough for use as pharmaceutical agents. However, bortezomib, as an alkylboronic acid, containing an atom with a lone electron pair in the $\beta$-position, is distinguished by the relative lability. The half-life of bortezomib in human plasma is 9-15 hours [8]. One of the products of its decomposition is boric acid. Boric acid, like boronic acid, tends to form complexes with diol-containing compounds. It can also lead to changes in the structure of antigens. Therefore, models of the corresponding complexes with boric acid were also included the calculation (Fig. 6).

The calculation of energy parameters and geometry of molecular systems and complexes was carried out in the HyperChem 8.07 software package by the methods of molecular mechanics (AMBER force field) and the semi-imperial PM3 method using the Polak-Ribier algorithm (gradient $0.01 \mathrm{kcal} / \AA$ mol). The optimization of geometry of complexes was carried out by minimization of system energy

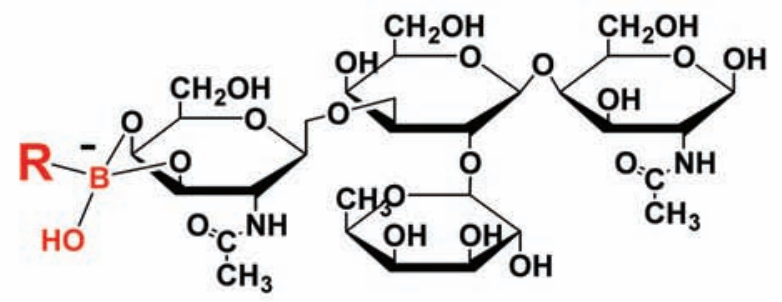

Bb-A

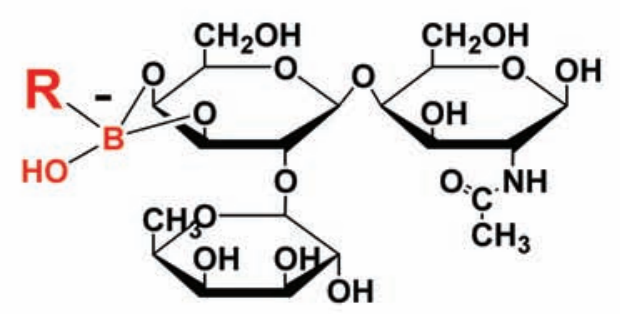

Bb-O

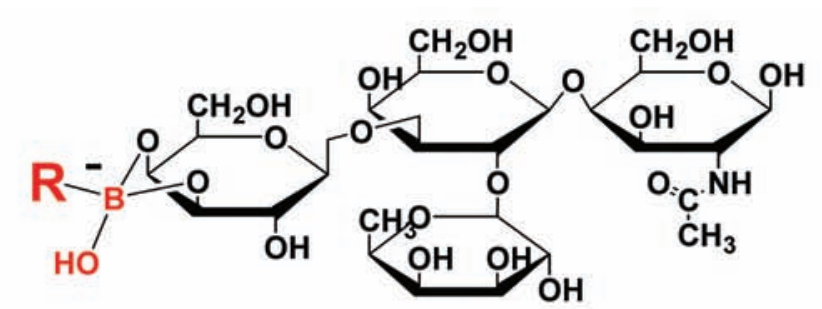

$\mathrm{Bb}-\mathrm{B}$<smiles>[R][X]C(C)CC(C)NC(=O)C(Cc1ccccc1)NC(=O)c1cnccn1</smiles>

Fig. 5. Structural formulas of model complexes of bortezomib $(\mathrm{Bb})$ with carbohydrate branch of blood antigens $(A, B, O)$ 


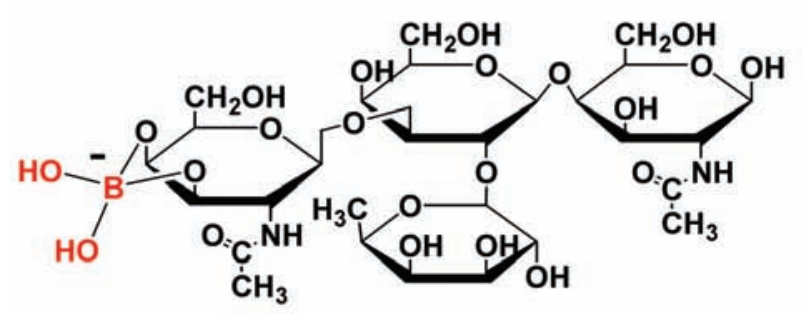

Ba-A

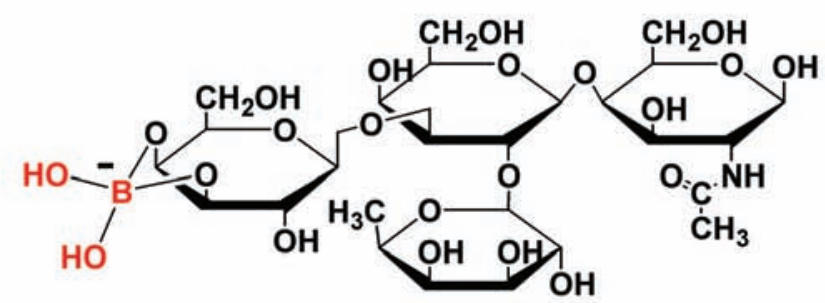

Ba-B

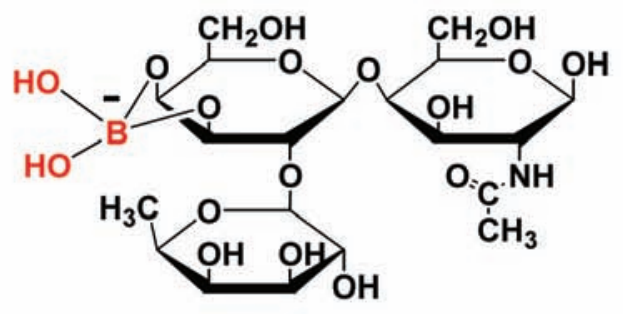

Ba-O

Fig. 6. Structural formulas of model complexes of boric acid (Ba) with carbohydrate branch of blood antigens $(O, A, B)$

with the change in its geometry and, as a result, with determination of the most stable conformation. The optimization of the system was carried out by minimization of the total energy of both molecules in vacuum $\left(E_{\mathrm{v}}\right)$ and solvated systems $\left(\mathrm{E}_{\mathrm{s}}\right)$, in order to determine the influence of the solvent on the optimal structure. In order to simulate the behavior of complexes in aqueous solution, as in the biological system, the molecules were placed in a periodic block with water molecules. The calculations used a block in the form of a cube with a side of 18 to $25 \AA$ depending on the size of the molecular system. In order to optimize energy, the simulation of molecular dynamics in solution $\left(\mathrm{E}_{\mathrm{sd}}\right)$ was also studied. The process of simulation of dynamics had three phases: heating, movement, and cooling.

\section{Results and Discussion}

On the basis of the preliminary distribution analysis of erythrocytic antigens of the ABO blood system in groups of examined patients with PCM, a probable $(P<0.05)$ increase in the carriage of phenotype B (III) in patients with CRF was established. The obtained data are confirmed by the imbalance of genetic equilibrium due to the increase of the frequency of allele $I^{B}$ in patients with CKD comparing to the control group. It was also found that in patients with phenotype A (II), probable $(P<0.05)$ duration of remission was longer. Thus, the dependence of the course of the disease on the carriage of the AFO phenotype is shown.

Affinity of drugs with antigens was estimated by change of total energy $(\Delta \mathrm{E})$ of bimolecular system (drug \& antigen) as a result of change of distance between molecules from infinity to best approximation in vacuum $\left(\Delta \mathrm{E}_{\mathrm{v}}\right)$, in water solution $\left(\Delta \mathrm{E}_{\mathrm{s}}\right)$ and after modelling of molecular dynamics $\left(\Delta \mathrm{E}_{\mathrm{sd}}\right)$ (Table 1). The calculation of energy parameters and geometry of molecular systems and complexes was carried out by the methods of molecular mechanics, (AMBER force field, gradient $0.001 \mathrm{kcal} / \AA \mathrm{mol}$ ). We do not provide absolute values of total energy of supramolecular systems, because its absolute value, calculated in this way applying any force field, has no real physical meaning. However, the difference in the calculated energies for two or more conformations has a physical meaning as a comparison of the relative conformational energies or differences in the conformational energies of different molecules.

Based on performed calculations, models of bimolecular systems of bortezomib and antigens were developed (Fig. 7).

Probability of existence of supramolecular complexes bortezomib-antigen was estimated by the change of Gibbs free energy (Table 2) of their formation $(\Delta \mathrm{G})$ as per the scheme:

$$
\text { Antigen }+{\mathrm{Bb}-\mathrm{OH}^{-} \rightarrow \mathrm{Bb}^{-} \text {Antigen }}^{-}+2 \mathrm{H}_{2} \mathrm{O} \text {. }
$$


Ta b le 1. Changes of total energy ( $\triangle E)$ of drug and antigen bimolecular systems as a result of change of distance between molecules from infinity to the best approximation

\begin{tabular}{l|c|c|c|c|c|c}
\hline \multirow{2}{*}{$\Delta \mathrm{E}, \mathrm{kcal} / \mathrm{mol}$} & \multicolumn{5}{|c}{ Drug and antigen biomolecular systems } \\
\cline { 2 - 7 } & $\mathrm{Bb} \mathrm{\&} \mathrm{O}$ & $\mathrm{Bb} \& \mathrm{~A}$ & $\mathrm{Bb} \mathrm{\&} \mathrm{B}$ & $\mathrm{Ba} \& \mathrm{O}$ & $\mathrm{Ba} \& \mathrm{~A}$ & $\mathrm{Ba} \& \mathrm{~B}$ \\
\hline \multirow{2}{*}{$\mathrm{E}_{\mathrm{v}}$} & -6.182 & -8.324 & -13.092 & -5.262 & -5.915 & -4.134 \\
$\Delta \mathrm{E}_{\mathrm{s}}$ & -9.397 & -9.460 & -14.912 & -5.100 & -6.863 & -2.113 \\
$\Delta \mathrm{E}_{\mathrm{sd}}$ & -10.229 & -9.603 & -18.740 & -6.216 & -6.943 & -6.725 \\
\hline
\end{tabular}

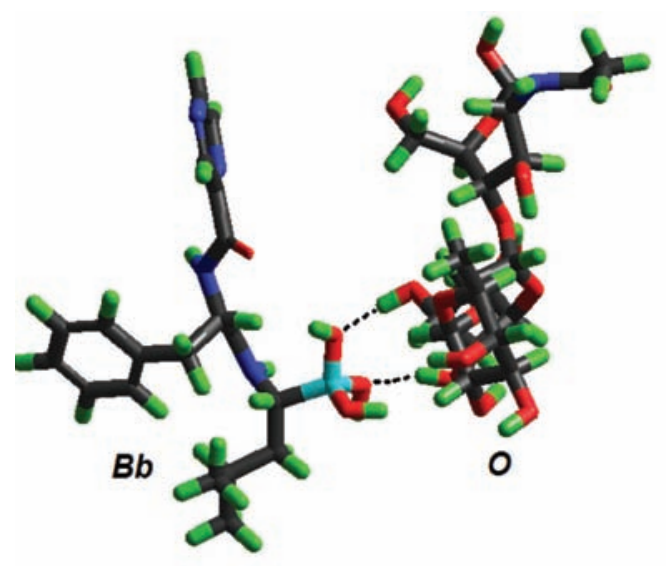

a

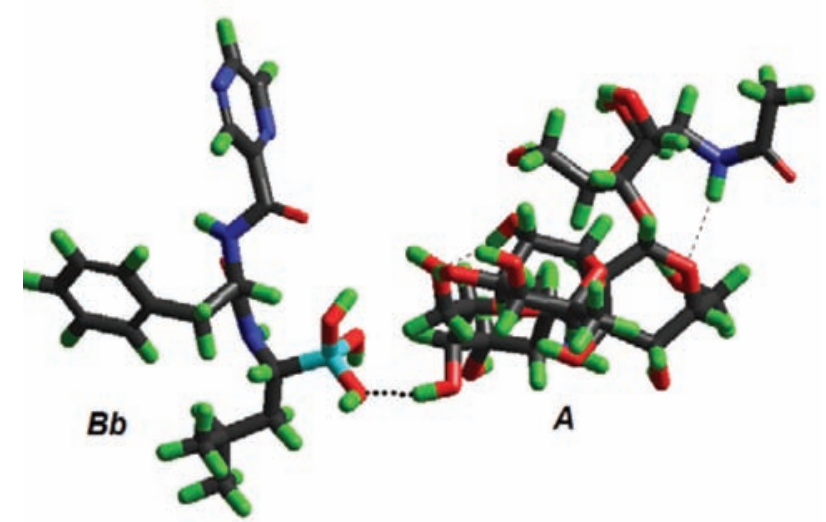

$\boldsymbol{b}$

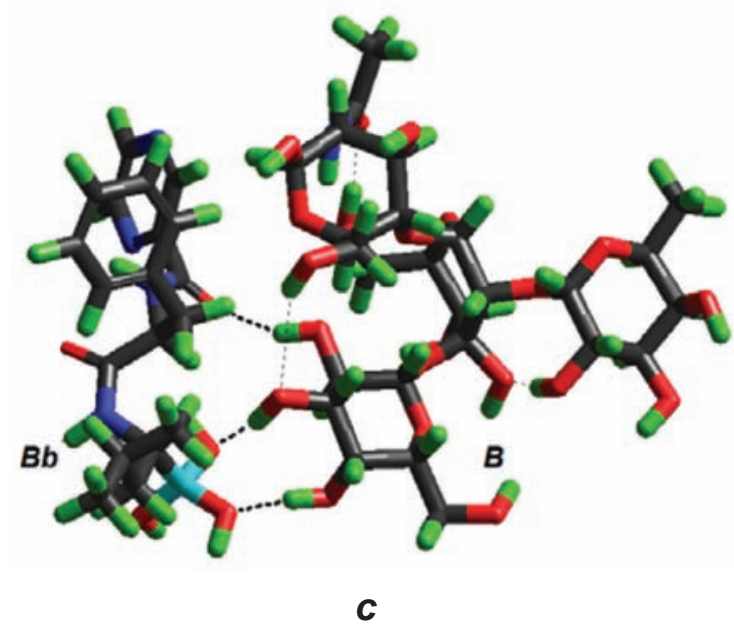

Fig. 7. Models of stabilized bimolecular systems of bortezomib (Bb) and antigens $(O, A, B): \boldsymbol{a}-B b \& O ; \boldsymbol{b}-B b$ $\& A ; c-B b \& B$

Table 2. Change of Gibbs free energy of bortezomib-antigen complexes

\begin{tabular}{c|c|c|c}
\hline Complexes & $\mathrm{Bb}-\mathrm{O}$ & $\mathrm{Bb}-\mathrm{A}$ & $\mathrm{Bb}-\mathrm{B}$ \\
\hline$\Delta \mathrm{G}, \mathrm{kcal} / \mathrm{mol}$ & -2.18 & -2.91 & -11.62 \\
\hline
\end{tabular}

The calculation of Gibbs free energy of complexes was carried out by the semi-imperial PM3 method. The model of the most stable complex Bb-B is shown in Fig. 8. 


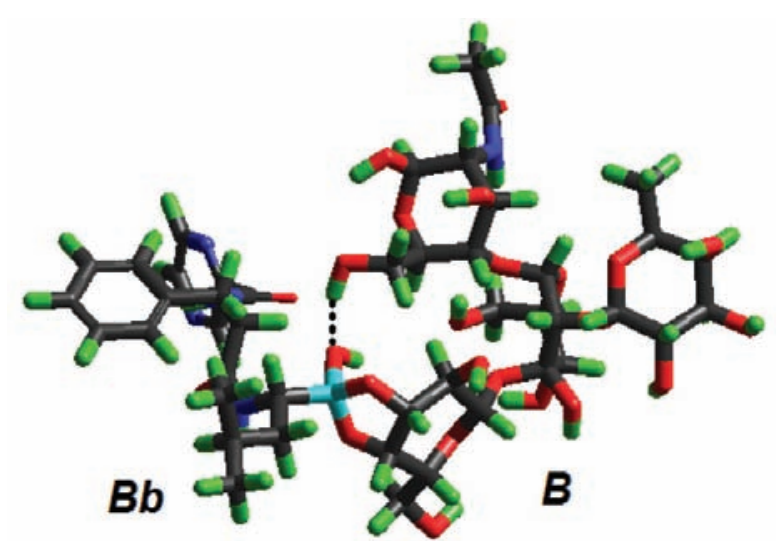

Fig.8. Models of stabilized Bb-B complex

The results of calculations provided in Table 1 points to the higher affinity of bortezomib to antigens in comparison with boric acid. Obviously, the formation of supramolar complexes with boric acid in general is unlikely, taking in account comparatively high values of $\Delta \mathrm{E}_{\mathrm{sd}}$. In addition, these values almost do not depend on the structure of the antigen, which does not correlate with the results of clinical researches. Therefore, the possibility of formation of supramolecular complexes boric acid - antigen can be ignored.

The affinity of bortezomib to antigens increases in the raw $\mathrm{A}<0<<\mathrm{B}$ (value $\Delta \mathrm{E}$ decreases, Table 1), hich can be explained by increase of the number of hydrogen bonds between bortezomib molecule and antigen in this raw (Fig. 7). In antigen A, a hydroxyl C3 group of galactose forms a hydrogen bond with one hydroxyl group of boronic acid. In antigen $\mathrm{O}$, two hydroxyl groups of galactose (C3 and C4 positions) form two hydrogen bonds with hydroxyl groups of the drug. The galactose of antigen $\mathrm{B}$ forms two hydrogen bonds (C3 and C4 positions) with hydroxyl groups of bortezomib and one hydrogen bond (C2 position) with the carbonyl group of peptide substituent of bortezomib. Obviously, high affinity of bortezomib to antigen $\mathrm{B}$ (low value $\Delta \mathrm{E}_{\mathrm{sd}}$ ) is the result of their complementarity.

Negative values of the change of Gibbs free energy in all complexes of bortezomib-antigen shows the principal opportunity of their formation (Table 2). According to the values of the change in free energy, the ability to complex formation with bortezomib varies in a number of antigens in the following way:

$$
\mathrm{B} 1>>\mathrm{O} 1>\mathrm{A} 1 \text {, }
$$

that is in line with the results of clinical trials.

The model of the most stable complex bortezomib-antigen $\mathrm{Bb}-\mathrm{B}$ is shown in Fig. 8. The complex is additionally stabilized by a hydrogen bond between the bortezomib free hydroxyl group and the C6 hydroxyl group of the N-Acetylgalactosamine of antigen B. The calculations did not take into account the influence of the peptide branch of the antigens, which may reveal itself in the additional stabilization of Bb-B complex, and stabilization can occur both due to hydroxyl groups of boronic acid (as shown in Fig. 3) and due to hydrogen bonds between functional groups of bortezomib and antigen peptide.

Calculations confirm the assumption made about the increased probability of the formation of bortezomib complexes with blood antigen of group B. It can be assumed that the reaction of complex formation with this glycoprotein forms the basis for forming a competitive relationship with the target drug reaction. Thus, in patients with a blood group in a byproduct (interaction of a bortezomib with anti-carbohydrate) energy is more advantageous than the main (inhibition of proteasome), and for patients with $\mathrm{O}$ and $\mathrm{A}$ groups, the equilibrium is shifted towards the main reaction. Since complex formation mostly takes place in alkaline medium, this fact should be taken into account when administration the drug with an alkaline reaction in patients with renal insufficiency, at least during the day after the administration of bortezomib (according to its halflife period in plasma), especially in patients with blood group B.

It should be noted that the work was performed in order to interpret the results of the clinical experience; therefore, the assumptions made in the work should be verified in subsequent clinical studies.

Conflict of interest. Authors have completed the Unified Conflicts of Interest form at http:// ukrbiochemjournal.org/wp-content/uploads/2018/12/ coi_disclosure.pdf and declare no conflict of interest. 


\section{РОЗРАХУНОК \\ СУПРАМОЛЕКУЛЯРНИХ \\ СТРУКТУР ПЕПТИДИЛБОРОНОВОЇ КИСЛОТИ (БОРТЕЗОМІБУ) 3 АНТИГЕНАМИ АВО СИСТЕМИ КРОВI}

\author{
А. Д. Кустовська ${ }^{1 \bowtie}$, С. В. Примаченко \\ Ж. М. Мінченко 2 Т. Ф. Любарецьь², \\ О. О. Дмитренко
}

${ }^{1}$ Національний авіаційний університет, Київ, Україна; 凶e-mail: akust@bigmir.net;

${ }^{2} Д У$ «Національний науковий центр радіаційної медицини НАМН України», Київ

Пептидилборонові кислоти набули поширення як ефективні препарати для лікування раку. Однак застосування цих препаратів часто супроводжується негативними побічними ефектами, які пов'язані з фенотиповою належністю до системи АВО. Тому визначення ролі фармако-хімічних характеристик антигенів системи ABO та лікувальних засобів (на прикладі бортезомібу) у виборі індивідуалізованих програм терапії хворих на хронічні лімфопроліферативні новоутворення $є$ важливим. Показано доцільність та ефективність застосування бортезомібу в пацієнтів із плазмоклітинною мієломою залежно від фенотипової належності до системи АВО. Ефективність терапії плазмоклітинної мієломи проаналізовано у 104 пацієнтів, які отримували лікування відповідно до клінічних протоколів. Вивчали тривалість ремісії у разі проведення стандартної поліхіміотерапії. Розрахунок енергетичних параметрів та геометрії ймовірних супрамолекулярних структур пептидилборонової (бортезомібу) та борної кислот iз антигенами АВО системи крові виконували в пакеті програм НурerChem 8.07. Показано, що здатність антигенів утворювати супрамолекулярні комплекси з бортезомібом змінюється в ряду: В1 > 01 > А1 відповідає результатам клінічних досліджень. Зроблено припущення, що для пацієнтів із групою крові В побічний процес (взаємодія бортезомібу з вуглеводом антигену) енергетично вигідніше, ніж основний (інгібування протеасоми), а для пацієнтів із групами крові О і А рівновага зміщується в бік основної реакції, що виявляється в терапевтичному ефекті препарату.
К л ю ч о в і с ло в а: пептидилборонові кислоти, супрамолекулярні структури, антигени АВО, бортезоміб, борна кислота.

\section{References}

1. Hall DG.(Ed.). Boronic acids: preparation, applications in organic synthesis and medicine. John Wiley \& Sons, 2006. 549 p.

2. Chen D, Frezza M, Schmitt S, Kanwar J, Dou QP. Bortezomib as the first proteasome inhibitor anticancer drug: current status and future perspectives. Curr Cancer Drug Targets. 2011; 11(3): 239-253.

3. Huber EM, Heinemeyer W, Groll M. Bortezomib-resistant mutant proteasomes: structural and biochemical evaluation with carfilzomib and ONX 0914. Structure. 2015; 23(2): 407-417.

4. Harshbarger W, Miller C, Diedrich C, Sacchettini J. Crystal structure of the human $20 \mathrm{~S}$ proteasome in complex with carfilzomib. Structure. 2015; 23(2): 418-424.

5. Pitcher DS, de Mattos-Shipley K, Tzortzis K, Auner HW, Karadimitris A, Kleijnen MF. Bortezomib amplifies effect on intracellular proteasomes by changing proteasome structure. EBioMedicine. 2015; 2(7): 642-648.

6. Chandra A, Wang L, Young T, Zhong L, Tseng WJ, Levine MA, Cengel K, Liu XS, Zhang Y, Pignolo RJ, Qin L. Proteasome inhibitor bortezomib is a novel therapeutic agent for focal radiation-induced osteoporosis. FASEB J. 2018; 32(1): 52-62.

7. Spoerke ED, Jones B, Martinez A, Small L, Wheeler D, Wheeler J, Bacgand G. Molecular Biomimicry: Imitating Nature in Responsive Supramolecular Materials. No. SAND20176605C. Sandia National Lab. (SNL-NM), Albuquerque, NM (United States), 2017.

8. Godoy-Gallardo M, York-Duran MJ, HostaRigau L. Recent Progress in Micro/Nanoreactors toward the Creation of Artificial Organelles. Adv Healthc Mater. 2018; 7(5): 1700917.

9. Pizer R. Boron acid complexation reactions with polyols and $\alpha$-hydroxy carboxylic acids: Equilibria, reaction mechanisms, saccharide recognition. Inorganica Chim Acta. 2017; 467: 194-197.

10. Furikado Y, Nagahata T, Okamoto T, Sugaya T, Iwatsuki S, Inamo M, Takagi HD, Odani A, Ishihara K. Universal reaction mechanism of boronic acids with diols in aqueous solution: 
kinetics and the basic concept of a conditional formation constant. Chemistry. 2014; 20(41): 13194-13202.

11. Goy A, Gilles F. Update on the proteasome inhibitor bortezomib in hematologic malignancies. Clin Lymphoma. 2004; 4(4): 230237.

12. Hasinoff BB, Patel D, Wu X. Molecular Mechanisms of the Cardiotoxicity of the Proteasomal-Targeted Drugs Bortezomib and Carfilzomib. Cardiovasc Toxicol. 2017; 17(3): 237-250.

13. Guglielmi V, Nowis D, Tinelli M, Malatesta M, Paoli L, Marini M, Manganotti P, Sadowski R, Wilczynski GM, Meneghini V, Tomelleri G,
Vattemi G. Bortezomib-Induced Muscle Toxicity in Multiple Myeloma. J Neuropathol Exp Neurol. 2017; 76(7): 620-630.

14. Kanayama N, Kitano H. Interfacial recognition of sugars by boronic acid-carrying self-assembled monolayer. Langmuir. 2000; 16(2): 577-583.

15. Zhang XT, Dong HL, Niu ZL, Xu JM, Wang DY, Tong H, Jiang XZ, Zhu MF. Loading and Controlled Releasing of Anti-cancer Drug Bortezomib by Glucose-Containing Diblock Copolymer. Chinese Materials Conference. Springer, Singapore, 2017: 871-880.

16. Lorand JP, Edwards JO. Polyol complexes and structure of the benzeneboronate ion. $J$ Org Chem. 1959; 24(6): 769-774. 